2021-03

\title{
An evaluation of the social and economic impact of a Marine Protected Area on commercial fisheries
}

Rees, Sian

http://hdl.handle.net/10026.1/16695

10.1016/j.fishres.2020.105819

Fisheries Research

Elsevier BV

All content in PEARL is protected by copyright law. Author manuscripts are made available in accordance with publisher policies. Please cite only the published version using the details provided on the item record or document. In the absence of an open licence (e.g. Creative Commons), permissions for further reuse of content should be sought from the publisher or author. 
1 An evaluation of the social and economic impact of a Marine Protected Area on commercial

2 fisheries.

3 In Rees SE, Ashley M, Evans L, Mangi S, Sheehan EV, et al., Fisheries Research, 2021

4 DOI: $\underline{10.1016 / \text { i.fishres.2020.105819 }}$

5 Siân E. Rees ${ }^{1 *}$, Matthew Ashley ${ }^{1}$, Louisa Evans ${ }^{2}$, Stephen Mangi ${ }^{3}$, Emma V. Sheehan, ${ }^{1}$

6 Tom Mullier, ${ }^{1}$ Adam Rees ${ }^{1,4}$, Martin J. Attrill ${ }^{1}$

7

$8{ }^{1}$ University of Plymouth, School of Biological and Marine Science, University of Plymouth, Drake 9 Circus, Plymouth, PL4 8AA, UK.

$10{ }^{2}$ University of Exeter, 407. Amory C355b. Amory Building, University of Exeter, Rennes Drive, Exeter, 11 EX4 4RJ, UK.

$12{ }^{3}$ MRAG Ltd, 18 Queen St, Mayfair, London W1J 5PN, UK.

13 ' ${ }^{4}$ Blue Marine Foundation, South Building, Somerset House, London WC2R 1LA United Kingdom 14

15

*corresponding author 
This study is an insight into the spatial use and economic performance of a fishery and linked fisher wellbeing across economic, social and health domains over a 12 year timescale pre and post Marine Protected Areas (MPA) designation. Since the MPA designation, there has been an increase in vessels using static gear inside and outside the MPA with a significant positive trend for vessels using static gear inside the MPA. Over time, static gear landings have decreased by $110 \mathrm{~kg}$ per vessel per month though there has been a significant positive trend over time in value achieved (landings of $£ 1452$ per vessel per month), linked to catches of high value species such as lobster, which are linked to the reef ecosystem. Fishing activity providing high volume (weight) and value landings from vessels using mobile demersal gears within the MPA ceased in July 2008. Mobile demersal gear fishing effort has since increased significantly outside the MPA. The value of mobile demersal gear landings in 2017 are comparable to fishing activity prior to the MPA designation but has not reached the peak landings values of 2008 at the point of MPA designation. Fishers predominantly using mobile demersal gear report lower subjective wellbeing and material losses. Static gear fishers report higher levels of subjective wellbeing over time compared to their mobile demersal gear counterparts. Positive subjective wellbeing are pronounced when the fishers are involved with an independent working group. Sustainability across ecological, social and economic systems requires an integrated rather than sequential approach to fisheries management and marine conservation. 
The Sustainable Development Goals (SDGs) advocate a 'triple bottom line' approach to maintaining human wellbeing; these being economic development, environmental sustainability and social inclusion (UN General Assembly 2015). SDG Goal 14 to 'conserve and sustainably use the oceans, seas and marine resources for sustainable development' places the designation of Marine Protected Areas (MPAs), as a means to mitigate biodiversity loss, firmly within the economic and social context of global development. MPAs are recognised as having linked social and economic dynamics (Rees, Pittman et al. 2018) and thus (with the respective resource users) form a complex social-ecological system (SES) (Ostrom 2009). The science underpinning the need for MPAs is considered to be mature (Lubchenco and Grorud-Colvert 2015). MPAs where all forms of fishing are removed (no-take) are shown to be the most effective mechanism to restore and preserve biodiversity (Lester and Halpern 2008, Sala, Lubchenco et al. 2018). The parameters for the ecological success of an MPA further rely on the size of the MPA (large) and isolation of the MPA from human pressures (Edgar, Stuart-Smith et al. 2014). However, such thresholds for MPA success are unrealistic given that the majority of MPAs are small and located close to coastlines where much human activity exists (Halpern 2014).

Commercial fishing takes many forms and is widespread. Fishing often overlaps with MPAs and predates their designation. Whilst the objectives for MPAs are typically for conservation purposes, commercial fisheries are dependent on healthy functioning marine ecosystems (inside and outside MPAs), with many of the features of conservation interest (within MPAs) fundamental in supporting fish and shellfish during essential life history stages (Kritzer, DeLucia et al. 2016, Stewart and Howarth 2016). A more realistic pathway to sustainability will rely on the identification of synergies between conservation goals and fisheries management (Gaines, Lester et al. 2010, Brooker, Devenport et al. 2018, Rees, Sheehan et al. 2020). Ecosystem based fisheries management (EBFM) is proposed as a structured whole-of-system place-based planning process that uses adaptive 
management to provide opportunities to consider overarching management goals for the socialecological system (Levin, Essington et al. 2018).

It is reported that an overarching obstacle to improving the management of the marine environment is the limited empirical evidence of MPA impacts on socioeconomic outcomes despite the many descriptive arguments of the potential for economic benefits resulting from conservation (Wells, Ray et al. 2016, Rees, Sheehan et al. 2020). To date, there is very limited empirical evidence of how MPAs contribute towards human wellbeing and sustainable development (Haines, Hattam et al. 2018, UNEP-WCMC, IUCN et al. 2018). Studies to link ecological and social metrics are rare (Gaines, Lester et al. 2010, Pollnac, Christie et al. 2010). Studies that explicitly link the conservation goals of an MPA to the performance of commercial fisheries inside and outside an MPA are equally rare in the European context (Haines, Hattam et al. 2018). A global synthesis of the literature confirms that most empirical work evaluating the social impacts of MPAs has focussed on economic outcomes and the processes of governance that can support improved wellbeing (e.g., rights and participation) (Ban, Gurney et al. 2019). To improve the evidence base, this study offers an insight into the economic performance of a fishery and linked fisher wellbeing across economic, social and health domains over a 12-year timescale pre and post an MPA designation.

\subsection{Case study site and context} In June 2008, the United Kingdom's (UK) Department of Environment, Food and Rural Affairs (Defra) established a Statutory Instrument (SI), The Lyme Bay Designated Area (Fishing Restrictions) Order 2008, SI 2008/1584, under the Sea Fish (Conservation) Act 1967. The SI came in to force in July 2008 and prevented mobile fishing gear, namely dredging and trawling (mobile demersal fishing gear) in $206 \mathrm{~km}^{2}$ of Lyme Bay (SI 2008/1584). The SI enabled the reef and the inter reef sediment areas to be protected from mobile demersal fishing gear across a whole-site (Solandt, Mullier et al. 2019, Rees, Sheehan et al. 2020). Creating, at that time, the UK's largest and the most strongly protected MPA 
for reef features. Within the SI boundary, static gear fishing (pots and nets) and SCUBA diving to collect King scallops (Pecten maximus, Pectinidae) are permitted.

Overlapping and extending the $\mathrm{SI}$ is a $312 \mathrm{~km}^{2}$ Special Area of Conservation (SAC) designated under the European Union Habitats Directive 92/43/EEC to protect Annex I reef features. In 2013, the regional Inshore Fisheries and Conservation Authority's (IFCA) implemented byelaws to protect $236 \mathrm{~km}^{2}$ of reef across the SAC and the SI. Outside of the SI and within the SAC, fishers using mobile demersal fishing gear are allowed to fish between the reef features, where they are currently delineated. The combination of the SI and the SAC form the boundary of the Lyme Bay Marine Protected Area (MPA) Figure 1.

[inset Figure 1 here]

Since the initial SI closure in 2008, ecological data on macro benthic sessile and sedentary organisms have been collected annually. The results demonstrate that there have been positive responses for species richness, total abundance and assemblage composition inside the SI and abundances of seven out of thirteen indicator taxa showed a positive response inside the SI (Sheehan, Stevens et al. 2013, Davies, Attrill et al. 2020). These species were found in greater abundance on reef habitat and pebbly-sand habitat in areas within three years of being closed to mobile demersal fishing to areas outside the SI exposed to mobile demersal fishing (Sheehan, Cousens et al. 2013, Sheehan, Stevens et al. 2013). Collection of socio-economic data has been more limited, confined to one year post SI closure for the fishing industry (2009-2010). Initial results demonstrated that there had been displacement of the mobile demersal fishing fleet, but that permitted commercial fishing activities (fishing with pots) had proliferated within the SI closure (Mangi, Rodwell et al. 2011). In the three years post SI closure, data also shows that recreation participants (divers and anglers) and providers (charter boat operators and dive businesses), had increased their use of the area within the SI closure citing the recovery of the reef and the reduction in conflict with the mobile demersal fishing 
fleet as key reasons for undertaking their activity in the area (Rees, Rodwell et al. 2010, Rees, Mangi et al. 2015).

In 2011, a non-governmental organisation (NGO), the Blue Marine Foundation, formed a pro-active working group for the Lyme Bay MPA. An initial Memorandum of Understanding (MoU) between interested parties established the basis for the Working Group (the Lyme Bay Consultative Committee (LBCC)) for members to promote and implement best practice in fishery and conservation management. Fishery and conservation management actions included a voluntary Code of Conduct, proposed as a means of achieving effective management to maintain sustainable fishing practices within the Lyme Bay MPA. Wider partnership activities by the LBCC have included development of new markets and branding, investment in post-harvest icing infrastructure, knowledge-sharing and training activities.

\section{Methods}

\subsection{Fishing activity and landings 2005 - 2017 data collection and analysis}

Data on the weight and value of species landed by different gear types were obtained from the Marine Management Organisation (MMO) for each vessel that fished in Lyme Bay (International Council for the Exploration of the Sea (ICES) statistical rectangles 30E6 and 30E7, Figure 1) from 2005 to 2017. The catch data included the wet weight and value of landings from ports around Lyme Bay reported by fishers and fish merchants to the MMO. The dataset included the date the landing took place, species caught, ICES rectangle fished, and the gear type used. It is noted that these data could be underestimating the actual landings and fishing effort as there is no statutory requirement for fishers to declare their catches for 10 metre and under vessels. Landings records for 10 metre and under vessels were therefore collated from log sheets and landings declarations supplied by fishers and sales notes from buyers and sellers (MMO 2016). This log book data was cross referenced with 
the MMO landings data to provide a complete data set of weight and value of species landed by the under 10 and over 10 metre fishing fleet.

143 Information from management and enforcement agencies (MMO, IFCA) (sightings data and expert 144 opinion) were used to match locations of fishing effort as either inside or outside the MPA, treating 145 the SI as a whole site closure (reef in inter sediment areas) and the SAC as a feature based (reef)

146 closure to mobile demersal fishing gear. Data were further divided into vessels that are

147 predominantly set up for either mobile (specifically using mobile demersal gear - dredging and

148 trawling) or static gear fishing (pots and nets). Whilst it must be noted that individual fishers may (at

149 different times of year) switch to an alternate form of fishing to take advantage of available stocks,

150 e.g. predominantly mobile gear vessels may also set static gear (pots) for whelks. The gear

151 separation reflects activities which are no longer permitted in the SI section of the Lyme Bay MPA

152 and conservation (reef) features within the SAC that intersect with the IFCA "no mobile (demersal)

153 gear", byelaws. 


\subsection{Commercial Species}

155

156

157

158

Commercial species that are not subject to quota restrictions in ICES Area 7e, the ICES area that interacts with the study site, are the focus for this research. The under 10 metre commercial fleet, dominant in this section of Lyme Bay, receive less than $5 \%$ of UK fish quota allocation (Urquhart, Symes et al. 2014, Anbleyth-Evans and Williams 2018, MMO 2019). Additionally, landings of nonquota species are more linked to fishing opportunity and availability than quota allocated species (Urquhart 2014). Landings data for these non-quota species are presented within gear categories.

Static gear: Pots: brown crab (Cancer pagurus, Cancridae) and european lobster (Homarus gammarus, Nephropidae); SCUBA diver: king scallop (P. maximus); Other pots: whelk (Buccinum undatum, Buccinidae), common cuttlefish (Sepia officinalis, Sepia); Static nets: lemon sole (Microstomus kitt, Pleuronectidae).

Mobile demersal gear: Scallop dredge (king scallop P. maximus); demersal trawl (cuttlefish S. officinalis); demersal trawl (lemon sole M. kitt).

\subsection{Statistical analysis of fishing activity and landings data}

Fishing within the Lyme Bay MPA is dominated by smaller under $10 \mathrm{~m}$ (inshore) vessels that mainly fish within 6 mile from the shore. Under 10 metre vessels comprise approximately $74 \%$ of the total number of vessels registered to ports within Lyme Bay as a whole and $96 \%$ of vessels registered to ports within the boundary of the MPA. Over the 10 year evaluation period the number of under 10 metre vessels registered to ports within Lyme Bay MPA has remained stable, between 38 to 44 vessels, representing approximately $38-73$ at sea jobs (Rees, Ashley et al. 2016). In the same period, there were 1-4 over $10 \mathrm{~m}$ vessels registered to ports within the MPA, noting that post 2008 three of these vessels with scallop licences would operate predominantly outside the MPA boundary (Rees, Ashley et al. 2016). 
Fishing activity and landings data were separated into categories. First, the data were separated by

178

179

180

181

182

183

184 vessel gear type, mobile (demersal gear such as trawls or dredges) or static gear (such as pots, static nets or collection of seafood by scuba diving). Fishing effort data (number of vessels and number of trips per month) were separated spatially depending on if the vessel was recorded as fishing within the area of the MPA or outside, using a July to June year to reflect before and after designation of the SI.

Values such as fisheries landings for a species may rise and fall between years and do not necessarily provide a linear trend over time. Therefore, to visually identify if a trend over time occurred, annual data (2005/06 - 2016/17) were first plotted in line charts in Microsoft Excel to observe inter-year changes. To statistically test for the presence of a trend, Kendall's tau-b statistical tests were calculated in Statistical Package for the Social Sciences (IBM SPSS ${ }^{\circledR}$ ) to test for presence of a monotonic relationship between fishing effort or landings data and time (2010-2017). A significant positive or negative trend was assessed at the $95 \%$ confidence limit ( $>0.05)$. To test for changes between data from years before the SI closure and after, Welch's $t$-test was used as a more reliable test due to unequal variance present between data sets.

Three year averages were also compared where possible, to identify a change in average values between the most recent 3-year period and the three year periods previous to it (e.g. increase, decrease or no change in the 3-year average between 2012-2014, and 2015-2017).

\subsection{Fisher wellbeing}

A learning history approach was adapted to measure how the wellbeing of Lyme Bay fishers was impacted by regulatory and environmental change events over time (Douthwaite and Ashby 2005, K.E. Abernethy, Ö. Bodin et al. 2014). First, a multi-stakeholder workshop ( $n=16)$ was held to: i) develop an integrated timeline of events impacting Lyme Bay between 2005 and 2015, and; ii) prioritise key indicators of subjective and objective wellbeing. 
Following development of the event timeline, workshop participants were introduced to the concepts of subjective and objective wellbeing across the domains of social, economy, health and environment. Participants then identified and ranked in order of importance indicators they deemed most relevant to the wellbeing of Lyme Bay fishers. The workshop identified four indicators of subjective wellbeing (job satisfaction, income satisfaction, stress and conflict) and three objective indicators of material wellbeing (turnover/profit, investment in the industry and sales strategy) as the most important. These workshop results were used to design a questionnaire survey for fishers. Along a ten-year timeline, fishers were asked to identify a year when a specific aspect of subjective wellbeing, such as job satisfaction, was highest. They were asked to rank on a scale of 0-10 (none-complete/extremely high) their wellbeing at that time. They repeated this for the time of lowest and current wellbeing (as of 2015). Respondents were then asked to identify key events that explained the highest, lowest and current levels of wellbeing, i.e. changes in wellbeing over time. Finally, fishers were asked to rank perceived levels of support for the Lyme Bay MPA on a scale of 0-10 (no support - full support). Fishers were surveyed face to face in pre-arranged meetings. A total of 28 fishers using static and/or mobile demersal fishing gear were interviewed representing the main ports in the study region. Approximately 41 vessels were registered in Lyme Bay ports within the MPA boundary resulting in an interview sample size of $68 \%$. Of this sample 19 reported to operate predominately inside the MPA $(n=19)$ and 9 outside the MPA ( $n=9)$. For all survey analyses, fishers were categorised into three groups: static-gear fishers involved in the timeline for every respondent which could be aggregated, the highest or lowest data points were repeated each year at the same value until the next reported data point. This assumed that fishers did 
not experience dramatic changes in wellbeing in-between the years they nominated as significant and provided a mean ranking that better reflects the average scores of all respondents across the years.

\section{Results}

\subsection{Changes in fishing activity and spatial effort}

Overall, the number of vessels actively fishing inside and outside the Lyme Bay MPA and reporting landings from ICES statistical rectangles $30 \mathrm{E} 6$ and $30 \mathrm{E} 7$ per month, increased over the period 2004/05-2016/17, aside for those using mobile demersal gear inside the MPA (Figure 2). Fishing activity providing high volume (weight) and value landings from vessels using mobile demersal gears within the MPA ceased, following the SI closure in July 2008 (Figure 3). There is a corresponding increase in mobile demersal gear effort outside the MPA in the years following the SI designation. (Figure 2).

[insert figure 2 here]

There has been an increase in effort from vessels using static gear across the study region, with a significant positive trend for vessels using static gear inside the MPA between 2005/6 and 2016/17, Kendall's tau-b $0.489 p=0.03$ ) and increase of 7 vessels between the first and last 3-year average in the time series (Table 1).

[inset table 1 here]

Fishing effort (mean number of trips per month) for vessels with static gears increased significantly within the MPA in comparison of annual data before and after the $2008 \mathrm{SI}$ closure (Welch's $t$ test = 7.45, $p=<0.001$ ) and displayed smaller significant increase outside the MPA (Welch's $t$ test $=3.83, p$ 0.05) (Table 1, Figure 2). There was an increase of 223 fishing trips per month inside the MPA and 185 outside the MPA between the first 3-year average before the $2008 \mathrm{SI}$ closure and the most recent 3-year average (Table 1). 
Despite an increase in number of trips per month by vessels using static gear over the time series, there was a decrease in overall landings weight (Table 1). However, there was a significant positive trend over time in value of those landings from fishing activity using static gears inside the MPA (Kendall's tau-b $0.788 p=<0.001$ ) and outside (Kendall's tau-b $0.485 p=0.03$ ) (Table 1, Figure 3). last 3-year average for static gear landings inside the MPA and $£ 866$ (per vessel per month) for static gear landings from outside the MPA (Table 1).

[insert figure 3]

Mobile demersal gear effort (average number of trips per month) has displayed a significant positive trend outside the MPA during the study period (Kendall's tau-b 0.840, $p=>0.001$ ) (Table 1, Figure 2). There was also a significant increase in effort (number of trips) outside the MPA, from vessels using mobile demersal gears, when comparing years before and after the SI closure (Welch's $t$ test $=5.49$, $p<0.001)$. The increase in effort from vessels using mobile demersal gears outside the MPA following the SI closure provided increased value $(+£ 2231$ average per vessel per month) from landings, when comparing 2004/05-2007/08 and 2014/15-2016/17, 3-year averages (Table 1, Figure 3). Value of landings for vessels using mobile demersal gears in Lyme Bay have shown some return to those achieved prior to the SI closure, with a value of $f 9021$ (average per vessel per month), from landings outside the MPA in 2016/17. However, values have not reached the peak values prior to the SI closure, where inside the MPA alone landings per vessel per month in 2005/06 were valued at f15311 (Table 1, Figure 3).

3.2. Changes in landings weight and value related to species landings from Lyme Bay 2005/06 2016/17 (ICES rectangles 30E6 and 30E7)

Static gear fisheries month, $412 \%$ increase) of diver caught scallops between 3-year averages at either end of the time 

series (Table 2), had the greatest contribution to the significant uplift in value obtained for landings

275 from all static gear fishing effort, inside the MPA (Table 2). Due to high values for scallop landings in 276 all years since the SI closure, the positive trend in value over time, for landings from scallop diving 277 was not significant (Kendalls tau-b 0.44, $p=0.15$ ). 
Significant positive trends in landings from potting (combined crab and lobster landings) also contributed to the uplift in value inside the MPA $(+178 \mathrm{~kg}, 66 \%$ increase in weight, resulting in $+£ 628$, $104 \%$ increase in value) (weight Kendall's tau-b $=0.5, p=<0.01$; value Kendall's tau-b $=0.87, p=$ $<0.001)$. Increase in landings weight and value associated with potting fisheries also occurred outside the MPA (Table 2) with the 51\% increase in value over time also being significant (weight Kendall's tau-b $=0.36, p=0.1 ;$ value Kendall's tau-b =0.51, $p=0.01$ ).

Landings from net fisheries of the high value species, such as lemon sole $M$. kitt, also contributed to the uplift in value from static gear activity within the MPA $(+£ 285,4750 \%$ increase, Kendall's tau-b $0.75, p=0.005)$. Of the other trap fisheries targeting non-quota species, whelk $B$. undatum provided the largest contribution to value from static gear activity inside and outside the MPA in all years, especially within the MPA (Table 2). Landings of cuttlefish S. officinalis are extremely variable across years based on factors (such as previous recruitment strength, sea surface temperature, exploitation of stocks offshore) that influence the availability of the stock to the inshore fisheries. When available to the inshore fisheries this high value stock adds significantly to the overall value of the static trap fisheries. Excluding cuttlefish S. officinalis landings, whelk B. undatum average annual landings value, per vessel per month, from inside the MPA between 2014/15 - 2016/17 was $f 7832$.

High value associated with mobile demersal gear activity before the SI closure was due to scallop $P$. maximus landings (2005/6-07/08 3-year average, £11,479) (Table 3). Following the SI closure, increased landings of scallops from dredge activity, as well as greater landings of non-quota species associated with mobile demersal fishing effort occurred outside the MPA (Table 3). Significant positive trends in value from mobile demersal gear landings from outside the MPA occurred over time (all landings: Kendall's tau-b 0.840, $p=<0.001$ ). Scallop landings provided the greatest contribution to increase in weight and value over time from effort outside the MPA (Kendall's tau-b 
$0.66, p=<0.017)$. However, 3 -year average values over the final 3 -year period in the time series were still below those for scallop landings from within the MPA before the SI closure $(£ 4,717$ compared to $f 11,479)$ (Table 3). Increased whelk landings were also associated with vessels that had principally used mobile demersal gears (Table 3). There was a very large increase in weight and value of whelk landings associated with those vessels, which occur within 1-2 years of the SI closure (Table 3). This resulted in a significant increase when comparing years before and after the SI closure (Welch's $t$ test $=5.49, p<0.001$ ). The positive trend was not significant over the 12 year time series, as landings rapidly increased from a pre-closure 3 year average weight of $9 \mathrm{~kg}$ and value of $f 11$, to 3 year averages immediately post-closure of $1583 \mathrm{~kg}$ and $£ 968$ and remained high throughout the 9 year post-closure time series (value, Kendall's tau-b 0.32, $p=0.148$ ).

\subsection{Subjective wellbeing}

The subjective wellbeing data reveals different wellbeing trajectories over the past decade for different sub-sectors of the Lyme Bay fishery (Figure 4). On average across the ten-year period, mobile demersal gear fishers report lower levels of job and income satisfaction and higher levels of perceived stress and conflict than the static-gear fishers (Figure 4). For static gear fishers involved in the LBCC partnership, job and income satisfaction were high in 2005 (2005 job satisfaction: Static $Y=$ 7; income satisfaction: Static $Y=6.8)$ and have increased marginally in the last ten years (2015 reported job satisfaction: Static $Y=8.3$; income satisfaction: Static $Y=7.5)$. Perceived levels of stress and conflict were low for this group (2005 stress Static $Y=4.5$; conflict: Static $Y=3.4$ ) and have decreased over the last ten years (2015 stress: Static $Y=4.3$; conflict: Static $Y=2$ ) (Figure 4). This group of respondents identified the SI closure and LBCC partnership activities, in particular the Reserve Seafood brand and investments in port-storage and icing as the two most beneficial events. Gear conflicts prior to the closure in 2008, winter storms (2013/2014) and poor weather (2014-2015) were viewed as the most negative events. For static-gear fishers not involved in the LBCC partnership, job and income satisfaction were also high (2005 job satisfaction: Static N = 7.7; income satisfaction: Static $N=7.3$ ) but have decreased or remained steady over the last ten years (2015 job 
satisfaction: Static $N=5.9$; income satisfaction: Static $N=7.5$ ). Perceived levels of stress were moderate and have increased marginally over the last ten years (2005 stress: Static N =3.3; 2015 stress: Static $\mathrm{N}=4.3$ ). Perceived levels of conflict were moderate but have decreased to low levels in the last ten years ( 2005 conflict: Static $N=5.7 ; 2015$ conflict: Static $N=1.8$ ). Many of these fishers were initially negatively impacted by the closure in 2008 but, having converted to static gears, have experienced improvements in subjective wellbeing. Poor weather in 2014-2015 and low quotas, in particular the combination of the two, were the most important negative events reported by this group. For mobile demersal gear fishers, job and income satisfaction were high (2005 job satisfaction: Mobile= 9.3; income satisfaction: Mobile= 10) but declined sharply into low reported levels of subjective wellbeing in 2008 , at the point of the SI closure, (2008 job satisfaction: Mobile= 3.4; income satisfaction: Mobile= 3.4) and have steadily increased since (2015 job satisfaction: Mobile= 5; income satisfaction: Mobile= 6.6) (Figure 4). Perceived levels of stress and conflict were low, spiked in 2008 and have decreased steadily over the last ten years (2005 stress: Mobile $=2.4$; 2008 stress: Mobile=8.6; 2015 stress Mobile =4.3) (Figure 4). Individuals from this group (group $n=9$ ) reported examples of symptoms of psychological and physical ill health during the process for the SI closure, for example suicidal thoughts, heart problems and persistent headaches. Stress has reduced since due to increased experience, 'just getting on with things', and good catches for some species. With respect to conflict, where the SI closure reduced gear conflicts for many static-gear fishers, it increased gear conflicts outside of the closed area particularly when extended through the SAC bylaws in 2013. Overall, respondents identified 2007-2008 and 2014-2015 as the years in which they experienced the greatest impacts on their fishing activities and related subjective wellbeing. The introduction of the Lyme Bay SI closure in 2008 was the event mentioned the most often by respondents $(n=25)$. The event was identified as positive for $25 \%$ of respondents and negative for the majority of fishers (at the time), including those that used static gear in the SI closure but who had to change or adjust gears when the SI closure was established. Other events mentioned that had a consistently negative 
impact included quota limitations $(n=11)$, loans $(n=5)$, fuel and insurance costs $(n=5)$ and general concerns about future changes to regulation or the industry $(n=5)$. On the contrary, supporting more positive wellbeing, a number of fishers stated that they were always satisfied with fishing and their income from fishing $(n=7)$ while others mentioned that their satisfaction had improved $(n=7)$ or their stress levels decreased as a result of being older, having cleared debts and generally being more experienced $(n=5)$. In the latter few years, winter storms and general bad weather were identified as the events that had the greatest negative impact on fishers' wellbeing $(n=20)$. Half of these $(n=20)$ fishers surveyed reported 'pushing the weather' (going out in more dangerous sea conditions) when the weather had been bad for a while, or in order to avoid debt or use up quota.

365 The most recent comments linked to 2015 demonstrate that subjective wellbeing concerns are also 366 linked to a perception that the fishery is over crowded $(n=6)$ and there is gear conflict $(n=6)$. 


\subsection{Objective wellbeing}

Fishers stated their annual turnover for 2015 and estimated what percentage of their turnover was

profit. Ten respondents chose not to answer and two did not know. Data from respondents suggests that mobile demersal gear fishers turnover was substantially more $(+£ 200,000 ; n=9)$ than that of static gear fishers $(<£ 60,000 ; n=8)$, on average. In terms of profit, three static gear fishers replied that they made "no profit", "just enough to cover costs" and "the minimum wage". Data indicate that for mobile demersal gear fishers there are large disparities in profits with five respondents earning between $£ 10,000-£ 30,000$ per annum and the remaining three respondents earning between $£ 100,000$ and $+£ 250,000$.

In the ten years preceding 2015 , over $85 \%$ of the fishers we sampled across all sectors invested in their fishing business. Just over a third planned to invest further in the next five years with moderate confidence that future investments would be sufficiently profitable (Table 4). Investments related primarily to boat and gear renovation, upgrades or expansion with the aim of fishing more safely and/or for longer. The majority of these fishers did not have additional livelihoods. Only a few operators ( $n=3$ ) invested in processing or selling facilities.

Approximately a third of the catch from static-gear fishers is sold to local retailers, restaurants and hotels compared to $5 \%$ of the catch of mobile demersal gear vessels in Lyme Bay. On average, $15 \%$ of the catch of static-gear fishers involved in the LBCC partnership is now sold as 'Reserve Seafood' at a premium price directly to London. A third of fishers sampled across all sectors would prefer more local or direct sales, but noted as constraints the limitations of time after fishing, infrastructure and transport requirements, and the potential risks of maintaining a good selling price while relying on fewer buyers. 


\section{Discussion}

This study offers a first insight into the social and economic performance of a fishery over a 12-year timescale, covering a period pre and post an MPA designation. The results demonstrate that whilst there have been subjective and material losses for mobile demersal gear fisheries, there have been social and economic gains for fisheries predominantly operating static gear inside and outside the MPA. These fishers report higher levels of subjective wellbeing over time compared to their mobile gear counterparts. These parameters of subjective wellbeing are further pronounced when the fishers are involved with the LBCC partnership. The economic loss to mobile demersal gear fishers who were annexed from the MPA by the $\mathrm{SI}$ is significant. The high point of dredge caught scallop landings ( $\mathrm{kg}$ and $\mathrm{f}$ ) in 2005-2007 (prior to the SI) has never been repeated. For those mobile demersal gear fishers who were displaced or remained operating outside the SI part of the MPA, there has been an increase in weight and value of shellfish landings from grounds outside, in relation to increased effort outside the MPA. Self-reported turnover and profit data suggest that in 2015 mobile demersal gear fishers enjoyed higher returns from fishing than static gear fishers. offshore, to maintain an income, has increased the personal risk to these operators. Overall, mobile demersal gear fishers report much lower levels of subjective well-being linked to their livelihood. Such differences in social impacts between groups of fishing industry stakeholders reflect findings from other MPA interventions (McNeill, Clifton et al. 2018). The impacts of the MPA in Lyme Bay are therefore nuanced and dynamic over time. The main social and economic effect of the MPA (SI and SAC) has been due to the introduction of a spatial management measure that has enabled a clear separation of gear types that had previously been in conflict for fishing grounds. The introduction of the MPA has primed a behavioural response within the local fleet with a significant increase in static gear fishing effort within the boundary of the MPA and lower levels of perceived conflict. Fisheries which set pots for species such as whelks $B$.

417 undatum, cuttlefish S. officinalis) brown crab C. pagurus and european lobster H. gammarus all 
continue to make use of the MPA, as well as fisheries using nets for finfish species. Dive caught scallops P.maximus fishing effort has also significantly increased within the MPA as a direct result of the removal of mobile demersal gear. Demonstrated here is the rapid reflex of fisheries activity to MPAs with the conservation designation acting as a (fisheries) spatial management measures. The increase in static gear fisheries has triggered a local post-ante fisheries management response to limit further increases in static gear effort (https://www.devonandsevernifca.gov.uk). From a governance and sustainability perspective there has been a sequential response to the MPA designation rather than an integrated plan for fisheries and conservation. The lack of early integration of the synergistic effects has the potential to 'mask' or hinder MPA performance

427 (ecological goals) through the removal of one pressure and the unmanaged/unintended introduction of another.

The link between conservation designation and fisheries performance is a key tool to the delivery of ecosystem-based fisheries management. Noting that counterfactuals in social and economic protected area research are extremely challenging to identify (Ferraro and Pressey 2015) it is necessary to observe the findings of this study against wider data sources and trends. For example, any changes in landings by fishers using different gear must also be considered against factors affecting fishing site preferences, rather than simple assumptions of increased abundance. In the Lyme Bay SI, P. maximus and Cancer pagurus both continue to increase in abundance along with sessile species such ross coral Pentapora foliacea and Hydroids that create stable nursery habitats 437 for commercial species to settle and develop (Sheehan, Cousens et al. 2013, Sheehan EV, Holmes L et al. 2020). There has been a significant increase in landings weight and landings value of scallops P.maximus from within the MPA (dive caught) and landings value outside the MPA (dredge). For example, the national trend for scallop P.maximus landings (weight and value) into England by UK vessels decreased between 2009 and 2014, the period when the greatest increase in landings occurred from within Lyme Bay MPA (increased mean per vessel per month) (Elliott 2014). In agreement with this, the Lyme Bay MPA ecological studies have demonstrated greater abundances 
of P.maximus within the MPA (Sheehan, Stevens et al. 2013). This potentially signals that this fishery

445 (inside and outside the MPA) is directly benefitting from the MPA management that enables protection and recovery of the reef.

447 There have also been significant increases in landings of brown crab C. pagurus from sites both inside and outside the MPA. The ecological studies demonstrate an increased abundance of $C$. pagurus between 2008 and 2011 in benthic monitoring studies in regions outside the MPA but close to the boundary (Sheehan, Stevens et al. 2013). Interestingly, no corresponding observed abundance recorded from the ecological monitoring studies within the MPA. This suggests that the fishing effort has increased within the MPA to potentially 'top slice', by removing a proportion of the increased abundance. Set within the national performance, fisheries statistics, landings (weight and value) of crab to ports in England by UK vessels increased between 2009 and 2015, suggesting changes in Lyme Bay may be within this national trend (regardless of the MPA) (Elliott 2014).

In terms of the impact of MPAs on measures of subjective and objective wellbeing, the MPA (SI closure) designation was identified as the most impactful event on subjective wellbeing across the fishing sector interviewed. Subjective wellbeing improved for negatively impacted static and mobile fishers since establishment, yet mobile demersal gear fishers still reported lower levels of subjective wellbeing than static gear fishers. Objective measures of wellbeing suggest that mobile demersal gear fishers receive higher income returns from fishing than the static gear sector and that they continue to invest in the fishery, often investing in bigger boats to increase safety and number of days at sea. In their global review of MPAs, Ban et al. (2019) report overall benefits to wellbeing from MPAs and highlight that the benefits to subjective wellbeing are lower than objective measures of wellbeing, and find that older MPAs report more benefits. Our findings similarly suggest differences between subjective and objective measures of wellbeing, and indicate that wellbeing can recover over time post MPA establishment. Wellbeing benefits (Static gear) are most strongly attributed to the role of the Lyme Bay Consultative Committee. In particular, they perceived high 
benefits to their fishing business from the additional icing and port storage facilities and the Reserve Seafood brand, and more moderate benefits from the voluntary Code of Conduct and Fully Documented fisheries projects.

472 Finally, changes in effort, profits or landings data cannot be solely attributed to the MPA. The fishing industry is agile to markets and demand for seafood as well as being responsive to exogenous (e.g. price elasticity, environmental shocks) and endogenous factors (e.g. shifts in fishing technology, species-habitat interactions) driving the outcomes observed (van Putten, Kulmala et al. 2012). The rapid pace of change in the mobile gear fleet size is demonstrated clearly in the years preceding the MPA when there was a significant increase in mobile gear vessels (dredgers) in Lyme Bay. 2006/2007 was a "bumper" year for scallop P.maximus landings from the local fleet and it was also reported that additional vessels (with greater fishing capacity) joined the fleet in Lyme Bay from fishing grounds as far as Scotland and the Channel Islands where changes in scallop P.maximus availability and restricted access, fuelled displacement of their activity to Lyme Bay (Rees, Attrill et al. 2010). The arrival of this fleet operating over the reef, with a greater fishing capacity (compared to the local fleet) triggered the MPA designation to protect the reef habitat (Rees, Attrill et al. 2010).

Fishing for cuttlefish S. officinalis also demonstrates market agility and opportunity for the fleet. remain above $9^{\circ} \mathrm{C}$ (Bloor, Attrill et al. 2013, Bloor, Wearmouth et al. 2013). Both adults and subadults are then assumed to undertake an inshore migration to shallow water areas during the spring. Despite variable landings by volume (weight) cuttlefish provide high value landings to static-gear fishers operating inside the MPA, as well as fishers using mobile demersal and static gear outside the MPA. In good years (such as $2007 / 08$ or $2015 / 16$ ), the cuttlefish fishery provides a noticeable bonus income in spring months, between April and June. 
markets and now representing the highest value contribution to the overall landings value for static gear fisheries operating both inside and outside the MPA, and since the closure has contributed to overall landings value for mobile demersal gear fisheries diversifying into the whelk fishery. Mobile demersal gear fishers operating outside the MPA have potentially switched to pots to either take advantage of the market or supplement income due to displacement effects. Overall, whelks are not associated solely with the reef ecosystem but naturally occur on all broadscale habitats present in Lyme Bay. B. undatum are scavengers and carnivorous predators feeding on polychaetes, bivalves and carrion, feeding across the range of habitats present in Lyme Bay (Hancock 1967, Scolding, Richardson et al. 2007). In the UK as a whole, fishing effort has generally increased on whelk stocks due to displacement of effort from whitefish and pot fisheries and the development of improved markets. In recent years, whelks have become increasing valuable. In 2017 whelk landings into English ports represented the fifth most valuable landings stock after scallops, cuttlefish, crabs and lobster respectively (Lawler 2013).

\section{Conclusion}

Sustainability across ecological, social and economic systems is a key requirement to maintaining human wellbeing. Despite the fact that the majority of MPAs support fishing within and adjacent to their boundaries, fisheries management and conservation goals are largely unlinked in current management frameworks. Progress towards sustainability is therefore fractured. Social-ecological theory suggests that transformations to sustainability occur in 'niches' at local level (Lotz-Sisitka, Wals et al. 2015). Lyme Bay is an example of such a 'niche', a unique UK example where much research and community effort has been placed on documenting and securing sustainable outcomes. With more forethought given to the metrics used to define ecological change, an integrated rather than sequential approach to fisheries management, MPAs and fisheries can form a

517 positive social-ecological feedback loop. From this learning, wider social changes and transformations towards sustainability can potentially emerge. 
520 This research was funded by the Blue Marine Foundation and in-kind contributions from the

521 University of Plymouth and the University of Exeter. The authors would like to thank staff from the

522 Devon and Severn IFCA, the Southern IFCA, MMO and Seafish for providing data and input into this

523 research. Thanks to Spike Searle (Marrok Marine) for support with the questionnaire design. Most

524 importantly the authors would like to thank all the fishers who gave up their time to take part in our

525 research.

526 7. Data Availability Statement To remain GDPR compliant on the holding of social and economic data. Aggregated data is available on request to the corresponding author. 
530

531

532

533

534

Anbleyth-Evans, J. W. and C. Williams (2018). "Fishing for Justice: England's Inshore Fisheries' Social Movements and Fixed Quota Allocation." Human Geography 11(1): 28-43.

Ban, N. C., G. G. Gurney, N. A. Marshall, C. K. Whitney, M. Mills, S. Gelcich, N. J. Bennett, M. C. Meehan, C. Butler, S. Ban, T. C. Tran, M. E. Cox and S. J. Breslow (2019). "Well-being outcomes of marine protected areas." Nature Sustainability 2(6): 524-532.

Bloor, I. S. M., M. J. Attrill and E. L. Jackson (2013). A Review of the Factors Influencing Spawning, Early Life Stage Survival and Recruitment Variability in the Common Cuttlefish (Sepia officinalis). Advances in Marine Biology, Vol 65. M. Lesser. 65: 1-65.

Bloor, I. S. M., V. J. Wearmouth, S. P. Cotterell, M. J. McHugh, N. E. Humphries, E. L. Jackson, M. J. Attrill and D. W. Sims (2013). "Movements and behaviour of European common cuttlefish Sepia officinalis in English Channel inshore waters: First results from acoustic telemetry." Journal of Experimental Marine Biology and Ecology 448: 19-27.

Brooker, E., E. Devenport, C. R. Hopkins, S. Hennige, J. M. Roberts and C. Duncan (2018). "Scotland as a case study for how benefits of marine ecosystem services may contribute to the commercial fishing industry." Marine Policy 93: 271-283.

Davies, B. F. R., M. J. Attrill, L. Holmes, A. Rees, M. J. Witt and E. V. Sheehan (2020). "Acoustic Complexity Index to assess benthic biodiversity of a partially protected area in the southwest of the UK." Ecological Indicators 111: 106019.

Douthwaite, B. and J. Ashby (2005). Innovation histories: A method from learning from experience. ILAC Brief 5: 4.

Edgar, G. J., R. D. Stuart-Smith, T. J. Willis, S. Kininmonth, S. C. Baker, S. Banks, N. S. Barrett, M. A. Becerro, A. T. F. Bernard, J. Berkhout, C. D. Buxton, S. J. Campbell, A. T. Cooper, M. Davey, S. C. Edgar, G. Forsterra, D. E. Galvan, A. J. Irigoyen, D. J. Kushner, R. Moura, P. E. Parnell, N. T. Shears, G. Soler, E. M. A. Strain and R. J. Thomson (2014). "Global conservation outcomes depend on marine protected areas with five key features." Nature 506(7487): 216-220.

Elliott, M., Ellis, G, Murray, A, Pilgrim, S, Reade, S, Williamson, K, Wintz, P, (2014). UK Sea Fisheries Statistics 2014. M. M. Organisation.

Ferraro, P. J. and R. L. Pressey (2015). "Measuring the difference made by conservation initiatives: protected areas and their environmental and social impacts." Philosophical Transactions of the Royal Society B: Biological Sciences 370(1681): 20140270.

Gaines, S. D., S. E. Lester, K. Grorud-Colvert, C. Costello and R. Pollnac (2010). "Evolving science of marine reserves: New developments and emerging research frontiers." Proceedings of the National Academy of Sciences of the United States of America 107(43): 18251-18255. Haines, R., C. Hattam, M. Pantzar and D. Russi (2018). Study on the Economic Benefits of MPAs. Luxembourg, European Commission: 93.

Halpern, B. S. (2014). "Making marine protected areas work." Nature 506: 167.

Hancock, D. (1967). Whelks. Laboratory Leaflet (new series) No. 15, . Ministry of Agriculture, Fisheries and Food; Fisheries Laboratory, Burnham on Crouch, Essex, England.

K.E. Abernethy, Ö. Bodin, P. Olsson, Z. Hilly and A. Schwarz (2014). "Two steps forward, two steps back: The role of innovation in transforming towards community-based marine resource management in Solomon Islands." Global Environmental Change 28: 309-321. Kritzer, J. P., M.-B. DeLucia, E. Greene, C. Shumway, M. F. Topolski, J. Thomas-Blate, L. A. Chiarella, K. B. Davy and K. Smith (2016). "The Importance of Benthic Habitats for Coastal Fisheries." BioScience 66(4): 274-284.

Lawler, A. (2013). Determination of the Size of Maturity of the Whelk Buccinum undatum in English Waters - Defra project MF0231, Defra: 38.

Lester, S. E. and B. S. Halpern (2008). "Biological responses in marine no-take reserves versus partially protected areas." Mar Ecol Prog Ser 367. 

Coleman, L. R. Gerber, J. H. Grabowski, E. Houde, O. P. Jensen, C. Möllmann, K. Rose, J. N. Sanchirico and A. D. M. Smith (2018). "Building effective fishery ecosystem plans." Marine Policy 92: 48-57. Lotz-Sisitka, H., A. E. J. Wals, D. Kronlid and D. McGarry (2015). "Transformative, transgressive social learning: rethinking higher education pedagogy in times of systemic global dysfunction." Current Opinion in Environmental Sustainability 16: 73-80.

Lubchenco, J. and K. Grorud-Colvert (2015).
protection." Science 350(6259): 382-383.

Mangi, S. C., L. D. Rodwell and C. Hattam (2011). "Assessing the Impacts of Establishing MPAs on Fishermen and Fish Merchants: The Case of Lyme Bay, UK." Ambio 40(5): 457-468.

McNeill, A., J. Clifton and E. S. Harvey (2018). "Attitudes to a marine protected area are associated with perceived social impacts." Marine Policy 94: 106-118.

MMO. (2016). "Guidance Fishing data collection, coverage, processing and revisions." Retrieved January, 2016, from www.gov.uk/guidance/fishing-activity-and-landings-data-collection-andprocessing. MMO. (2019). "Current catch limits: 10 metres and under non-sector pool " Retrieved April 2020, from https://www.gov.uk/government/publications/current-catch-limits-10-metres-and-under-pool. Ostrom, E. (2009). "A General Framework for Analyzing Sustainability of Social-Ecological Systems." Science 325(5939): 419-422.

Pollnac, R., P. Christie, J. E. Cinner, T. Dalton, T. M. Daw, G. E. Forrester, N. A. J. Graham and T. R. McClanahan (2010). "Marine reserves as linked social-ecological systems." Proceedings of the National Academy of Sciences 107(43): 18262-18265.

Rees, S. E., M. Ashley, L. Evans, S. Mangi, L. Rodwell, M. Attrill, O. Langmead, E. Sheehan and A. Rees (2016). An evaluation framework to determine the impact of the Lyme Bay Marine Protected Area and the activities of the Lyme Bay Consultative Committee on ecosystem services and human wellbeing. A report to the Blue Marine Foundation by research staff the Marine Institute at Plymouth University, Exeter University and Cefas. Pp139.

Rees, S. E., M. J. Attrill, M. C. Austen, S. C. Mangi, J. P. Richards and L. D. Rodwell (2010). "Is there a win-win scenario for marine nature conservation? A case study of Lyme Bay, England." Ocean \& Coastal Management 53(3): 135-145.

Rees, S. E., S. C. Mangi, C. Hattam, S. C. Gall, L. D. Rodwell, F. J. Peckett and M. J. Attrill (2015). "The socio-economic effects of a Marine Protected Area on the ecosystem service of leisure and recreation." Marine Policy 62: 144-152.

Rees, S. E., S. J. Pittman, N. Foster, O. Langmead, C. Griffiths, S. Fletcher, D. E. Johnson and M. Attrill (2018). "Bridging the divide: Social-ecological coherence in Marine Protected Area network design." Aquatic Conservation: Marine and Freshwater Ecosystems 28(3): 754-763.

Rees, S. E., L. D. Rodwell, M. J. Attrill, M. C. Austen and S. C. Mangi (2010). "The value of marine biodiversity to the leisure and recreation industry and its application to marine spatial planning." Marine Policy 34(5): 868-875.

Rees, S. E., E. V. Sheehan, B. D. Stewart, R. Clark, T. Appleby, M. J. Attrill, P. J. S. Jones, D. Johnson, N. Bradshaw, S. Pittman, J. Oates and J.-L. Solandt (2020). "Emerging themes to support ambitious UK marine biodiversity conservation." Marine Policy: 103864.

Rees, S. E., E. V. Sheehan, B. D. Stewart, R. Clark, T. Appleby, M. J. Attrill, P. J. S. Jones, D. Johnson, N. Bradshaw, S. Pittman and J. L. Solandt (2020). "Emerging themes to support ambitious marine biodiversity conservation." Marine Policy (In Press).

Sala, E., J. Lubchenco, K. Grorud-Colvert, C. Novelli, C. Roberts and U. R. Sumaila (2018). "Assessing real progress towards effective ocean protection." Marine Policy 91: 11-13.

Scolding, J. W. S., C. A. Richardson and M. J. Luckenbach (2007). "Predation of cockles (Cerastoderma edule) by the whelk (Buccinum undatum) under laboratory conditions." Journal of Molluscan Studies 73: 333-337. 
Sheehan EV, Holmes L, Rees A, Cartwright A, Bridger D and A. MJ. (2020). "Rewilding enhances resilience of marine ecosystems to extreme climatic events." Nature Communications In prep. . Sheehan, E. V., S. L. Cousens, S. J. Nancollas, C. Stauss, J. Royle and M. J. Attrill (2013). "Drawing lines at the sand: Evidence for functional vs. visual reef boundaries in temperate Marine Protected Areas." Marine Pollution Bulletin 76(1): 194-202. Sheehan, E. V., T. F. Stevens, S. C. Gall, S. L. Cousens and M. J. Attrill (2013). "Recovery of a Temperate Reef Assemblage in a Marine Protected Area following the Exclusion of Towed Demersal Fishing." PLOS ONE 8(12): e83883. Solandt, J.-L., T. Mullier, S. Elliott and E. Sheehan (2019). Managing Marine Protected Areas in Europe: Moving from 'feature-based' to 'whole-site' management of sites, Elsevier.

Stewart, B. D. and L. M. Howarth (2016). Chapter 14 - Quantifying and Managing the Ecosystem Effects of Scallop Dredge Fisheries. Developments in Aquaculture and Fisheries Science. S. E. Shumway and G. J. Parsons, Elsevier. 40: 585-609.

UN General Assembly (2015). Transforming our world : the 2030 Agenda for Sustainable Development, 21 October 2015, A/RES/70/1, available at:

https://www.refworld.org/docid/57b6e3e44.html [accessed 26 February 2020]. UNEP-WCMC, IUCN and NGS (2018). Protected Planet Report 2018 Cambridge UK; Gland, Switzerland; and Washington, D.C., USA., UNEP-WCMC, IUCN and NGS: 70.

Urquhart, J. (2014). Introduction: Social Issues in Sustainable Fisheries Management. Social Issues in Sustainable Fisheries Management. J. Urquhart, T. Acott, D. Symes and M. Zhao. Netherlands, Springer 1-20.

Urquhart, J., D. Symes, T. Acott. and M. Zhao (2014). Social issues in sustainable fisheries management, Springer.

651 van Putten, I. E., S. Kulmala, O. Thébaud, N. Dowling, K. G. Hamon, T. Hutton and S. Pascoe (2012). 652 "Theories and behavioural drivers underlying fleet dynamics models." Fish and Fisheries 13(2): 216653235.

654 Wells, S., G. C. Ray, K. M. Gjerde, A. T. White, N. Muthiga, J. E. Bezaury Creel, B. D. Causey, J. 655 McCormick-Ray, R. Salm, S. Gubbay, G. Kelleher and J. Reti (2016). "Building the future of MPAs 656 lessons from history." Aquatic Conservation: Marine and Freshwater Ecosystems 26(S2): 101-125. 
660 Table 1 Range +/- between 3-year average pre SI closure (2004/05-2007/08 and the 3-year average >6years

661 post SI closure (2014/15-2016/17), significant monotonic trends (Kendall's tau-b) between 2004/05 and

662 2016/17 data are indicated by *.

\begin{tabular}{|c|c|c|c|c|c|c|c|c|c|}
\hline \multirow{2}{*}{$\begin{array}{l}\text { Gear } \\
\text { Category } \\
\text { and } \\
\text { Location }\end{array}$} & \multicolumn{2}{|c|}{$\begin{array}{l}\text { Wet weight mean per } \\
\text { vessel per month }(\mathrm{Kg})\end{array}$} & \multicolumn{2}{|c|}{$\begin{array}{l}\text { Value per vessel per } \\
\text { month (f) }\end{array}$} & \multicolumn{2}{|c|}{$\begin{array}{l}\text { Approximate number } \\
\text { of vessels per month }\end{array}$} & \multicolumn{2}{|c|}{$\begin{array}{l}\text { Approximate number } \\
\text { of trips per month by } \\
\text { all vessels }\end{array}$} & \multirow{2}{*}{$\begin{array}{l}\text { Overall } \\
\text { change } \\
\text { across } \\
\text { categories } \\
+/-\end{array}$} \\
\hline & $\begin{array}{l}2014- \\
2017, \\
3 \text {-year } \\
\text { average }\end{array}$ & $\begin{array}{l}\text { Change } \\
\text { over time } \\
2005 / 08 \\
\text { to } \\
2014 / 17\end{array}$ & $\begin{array}{l}\text { 2014- } \\
2017, \\
\text { 3-year } \\
\text { average }\end{array}$ & $\begin{array}{l}\text { Change } \\
\text { over time } \\
2005 / 08 \\
\text { to } \\
2014 / 17\end{array}$ & $\begin{array}{l}\text { 2014- } \\
2017, \\
\text { 3-year } \\
\text { average }\end{array}$ & $\begin{array}{l}\text { Change } \\
\text { over time } \\
2005 / 08 \\
\text { to } \\
2014 / 17\end{array}$ & $\begin{array}{l}\text { 2014- } \\
2017, \\
\text { 3-year } \\
\text { average }\end{array}$ & $\begin{array}{l}\text { Change } \\
\text { over time } \\
2005 / 08 \\
\text { to } \\
2014 / 17\end{array}$ & \\
\hline $\begin{array}{l}\text { Static } \\
\text { gear } \\
\text { inside. }\end{array}$ & 2851 & -110 & 3739 & $+1452^{*}$ & 36 & $+7^{*}$ & 281 & $+223^{*}$ & + \\
\hline $\begin{array}{l}\text { Static } \\
\text { gear } \\
\text { outside. }\end{array}$ & 1672 & -391 & 3399 & $+866^{*}$ & 52 & +12 & 343 & $+185^{*}$ & + \\
\hline $\begin{array}{l}\text { Mobile } \\
\text { gear } \\
\text { inside. }\end{array}$ & 0 & -6381 & 0 & -9960 & 0 & -7 & 0 & -52 & - \\
\hline $\begin{array}{l}\text { Mobile } \\
\text { gear } \\
\text { outside. }\end{array}$ & 5116 & -7659 & 8144 & 2231 & 21 & $+7^{*}$ & 144 & $+99 *$ & + \\
\hline
\end{tabular}

663

664 Table 2 Landings weight $(\mathrm{kg})$ and value $(\mathrm{f})$ associated with static gear fishing effort, most recent 3-

665 year average data in the time series (2014-17) are compared to the 3-year average before the SI

666 closure (2005-08) for gear types and associated non-quota species inside and outside the MPA.

\begin{tabular}{|c|c|c|c|c|c|c|c|}
\hline \multirow{2}{*}{$\begin{array}{l}\text { Gear } \\
\text { Category } \\
\text { and } \\
\text { Location }\end{array}$} & \multirow{2}{*}{$\begin{array}{l}\text { Non-Quota } \\
\text { Species } \\
\text { Included }\end{array}$} & \multicolumn{3}{|c|}{ Weight (kg) } & \multicolumn{3}{|c|}{ Value (f) } \\
\hline & & $\begin{array}{l}\text { 2014-2017 } \\
\text { Average }\end{array}$ & $\begin{array}{l}\text { Change over } \\
\text { time } \\
2005 / 08 \text { to } \\
2014 / 17\end{array}$ & $\%$ change & $\begin{array}{l}\text { 2014-2017 } \\
\text { Average }\end{array}$ & $\begin{array}{l}\text { Change over } \\
\text { time } \\
2005 / 08 \text { to } \\
2014 / 17\end{array}$ & $\begin{array}{l}\% \\
\text { change }\end{array}$ \\
\hline \multicolumn{8}{|c|}{ Static gear inside the MPA } \\
\hline Pots & Crab, Lobster & 448 & $\underline{178 *}$ & $\uparrow 66 \%$ & 1232 & $\underline{628 *}$ & $\uparrow 104 \%$ \\
\hline Scuba Dive & Scallop & 1008 & $\underline{735^{*}}$ & $\uparrow 177 \%$ & 1874 & 1507 & $\uparrow 412 \%$ \\
\hline Other Traps & Whelk, Cuttlefish & 8268 & -4803 & $\downarrow 37 \%$ & 8456 & 311 & 个 $4 \%$ \\
\hline Nets & Lemon sole & 58 & $\underline{57 *}$ & $\uparrow 5700 \%$ & 291 & $\underline{285 *}$ & $\uparrow 4750 \%$ \\
\hline \multicolumn{8}{|c|}{ Static gear outside the MPA } \\
\hline Pots & Crab, Lobster & 966 & 183 & $\uparrow 24 \%$ & 2700 & 909* & $\uparrow 51 \%$ \\
\hline Scuba Dive & Scallop & 2459 & -559 & $\downarrow 0.18 \%$ & 3524 & -2059 & $\downarrow 0.37 \%$ \\
\hline Other Traps & Whelk, Cuttlefish & 3955 & -3714 & $\downarrow 0.48 \%$ & 3798 & -560 & $\uparrow 13 \%$ \\
\hline Nets & Lemon sole & 2 & -93 & $\downarrow 98 \%$ & 10 & -364 & $\downarrow 97 \%$ \\
\hline
\end{tabular}


Table 3 Landings weight $(\mathrm{kg})$ and value $(\mathrm{f})$ associated with mobile demersal gear fishing effort, most recent 3-year average data in the time series (2014-17) are compared to the 3-year average before the SI closure (2005-08) for gear types and associated non-quota species inside and outside the MPA, * indicates significant positive or negative trends.

\begin{tabular}{|c|c|c|c|c|c|c|c|}
\hline \multirow{2}{*}{$\begin{array}{l}\text { Gear } \\
\text { Category } \\
\text { and } \\
\text { Location }\end{array}$} & \multirow{2}{*}{$\begin{array}{l}\text { Non- } \\
\text { Quota } \\
\text { Species } \\
\text { Included }\end{array}$} & \multicolumn{3}{|c|}{ Weight (kg) } & \multicolumn{3}{|c|}{ Value (f) } \\
\hline & & $\begin{array}{l}2014- \\
2017 \\
\text { Average }\end{array}$ & $\begin{array}{l}\text { Change } \\
\text { over time } \\
2005 / 08 \text { to } \\
2014 / 17\end{array}$ & $\%$ change & $\begin{array}{l}2014- \\
2017 \\
\text { Average }\end{array}$ & $\begin{array}{l}\text { Change } \\
\text { over time } \\
2005 / 08 \text { to } \\
2014 / 17\end{array}$ & $\%$ change \\
\hline \multicolumn{8}{|c|}{ Mobile gear inside the MPA } \\
\hline $\begin{array}{l}\text { Scallop } \\
\text { dredge }\end{array}$ & Scallop & 0 & -7705 & $\downarrow 100 \%$ & 0 & $\underline{-11479 *}$ & $\downarrow 100 \%$ \\
\hline $\begin{array}{l}\text { Trawl / } \\
\text { mobile nets }\end{array}$ & $\begin{array}{l}\text { Lemon } \\
\text { sole }\end{array}$ & 0 & -22 & $\downarrow 100 \%$ & 0 & $\underline{-121 *}$ & $\downarrow 100 \%$ \\
\hline Trawl & Cuttlefish & 0 & -365 & $\downarrow 100 \%$ & 0 & $\underline{-442 *}$ & $\downarrow 100 \%$ \\
\hline Trap & Whelk & 0 & -6 & $\downarrow 100 \%$ & 0 & -3 & $\downarrow 100 \%$ \\
\hline \multicolumn{8}{|c|}{ Mobile gear outside the MPA } \\
\hline $\begin{array}{l}\text { Scallop } \\
\text { dredge }\end{array}$ & Scallop & 3889 & 1540 & 个 65\% & 8216 & $\underline{4717^{*}}$ & $\uparrow 136 \%$ \\
\hline $\begin{array}{l}\text { Trawl / } \\
\text { mobile nets }\end{array}$ & $\begin{array}{l}\text { Lemon } \\
\text { sole }\end{array}$ & 357 & $\underline{308^{*}}$ & 个 $628 \%$ & 1587 & $\underline{1362 *}$ & $\uparrow 605 \%$ \\
\hline Trawl & Cuttlefish & 689 & 469 & 个 $213 \%$ & 1586 & 1315 & $\uparrow 485 \%$ \\
\hline Trap & Whelk & 839 & 830 & 个 $9222 \%$ & 810 & 800 & 个 $7900 \%$ \\
\hline
\end{tabular}

672 Table 2 Past and future investment in the fishing industry, and sales strategy for static-gear fishers

673 involved in the Lyme Bay Consultative Committee (Static Y), static gear fishers not involved in LBCC

674 (Static N) and mobile demersal gear fishers.

\begin{tabular}{|c|c|c|c|c|}
\hline & Objective wellbeing metrics & $\begin{array}{c}\text { Static } \\
\text { (Y) }\end{array}$ & $\begin{array}{c}\text { Static } \\
(\mathrm{N})\end{array}$ & Mobile \\
\hline \multirow[t]{3}{*}{ Investment } & $\begin{array}{l}\text { Proportion of respondents who have invested } \\
\text { previously }\end{array}$ & $100 \%$ & $75 \%$ & $80 \%$ \\
\hline & $\begin{array}{l}\text { Proportion of respondents with plans to invest in } \\
\text { the next five years }\end{array}$ & $20 \%$ & $50 \%$ & $50 \%$ \\
\hline & $\begin{array}{l}\text { Average confidence that future investment will be } \\
\text { beneficial (score } 0-10 \text { with } 10 \text { being extremely high } \\
\text { confidence) }\end{array}$ & $8.0 / 10$ & $6.5 / 10$ & $7.1 / 10$ \\
\hline \multirow{3}{*}{$\begin{array}{c}\text { Sales } \\
\text { strategy }\end{array}$} & Reserve Seafood brand & $15 \%$ & & \\
\hline & Local shops and restaurants & $38 \%$ & $22 \%$ & $5 \%$ \\
\hline & Processors / auctions & $47 \%$ & $78 \%$ & $95 \%$ \\
\hline
\end{tabular}


677 Figure 1 The Lyme Bay Marine Protected Area (MPA) comprising of the Statutory Instrument - The Lyme Bay Designated Area (Fishing Restrictions Order) and the European Union Habitats Directive 92/43/EEC Special Area of Conservation.

680

Figure 2 Number of vessels per month (mean) and Number of trips per month (mean) actively fishing 681 inside and outside the Lyme Bay MPA for a) static gear inside the MPA b) mobile demersal gear inside the MPA c) static gear outside the MPA d) mobile gear outside the MPA.

Figure 3: Wet weight of landings $(\mathrm{kg})$ and value of landings $(f)$ per vessel per month for a) static gear vessels fishing inside the MPA, b) mobile demersal gear vessels fishing inside the MPA, c) static gear vessels fishing outside the MPA and d) mobile demersal gear vessels fishing outside the MPA.

Figure 4: Fishers' subjective wellbeing over time a) job satisfaction, b) income satisfaction, C) perceived levels of stress and d) perceived levels of conflict. Static $Y=$ fishers using static gear who are involved in the Lyme Bay Consultative Committee partnership. Static $\mathrm{N}=$ fishers using static gear who are not involved in the LBCC partnership. Mobile $=$ fishers using mobile demersal gears who are not involved in the LBCC partnership (with the exception of one respondent).

691

692

693

694 